\title{
Benthic Macrofauna Associated with Submerged Bottoms of a Tectonic Estuary in Tropical Eastern Pacific
}

\author{
Carlos E. Guevara-Fletcher, ${ }^{1,2}$ Jaime R. Cantera Kintz, ${ }^{1}$ \\ Luz M. Mejía-Ladino, ${ }^{2}$ and Fabián A. Cortés ${ }^{2}$ \\ ${ }^{1}$ Ecology of Estuaries and Mangroves Research Group "Ecomanglares", Biology Department, Faculty of Science, Universidad del Valle, \\ Calle 13, No. 100-00, 25360 Cali, Colombia \\ ${ }^{2}$ Programa Biodiversidad y Ecosistemas Marinos, Instituto de Investigaciones Marinas y Costeras "Jose Benito Vives de Andréis", \\ Recta Cali-Palmira 17km, 6713 C36 Cali, Colombia
}

Correspondence should be addressed to Jaime R. Cantera Kintz, jaime.cantera@correounivalle.edu.co

Received 15 May 2011; Accepted 24 July 2011

Academic Editor: Andrew McMinn

Copyright ( 2011 Carlos E. Guevara-Fletcher et al. This is an open access article distributed under the Creative Commons Attribution License, which permits unrestricted use, distribution, and reproduction in any medium, provided the original work is properly cited.

\begin{abstract}
The composition and distribution of the main associations of submerged macrobenthos of Bahía Málaga (Colombian pacific coast), were studied in relation to the distribution of hard and soft substrates and some abiotic factors. Eight localities were sampled during six months: three in the external border of the estuary and five in the inner part. In total, 728 organisms were registered, belonging to 207 species, 132 genera, 86 families, and 14 orders of six invertebrate groups (Porifera, Cnidaria, Polychaeta, Mollusca, Crustacea, and Echinodermata). The submerged bottoms presented soft and hard substrates, with rocks and thick sand in five sites, soft bottoms with fine sand in one, and soft bottoms with slime and clay in two. The temperature and salinity values were higher in the external localities, while dissolved oxygen and $\mathrm{pH}$ were higher in the internal localities. The localities with hard substrates presented the highest richness of species while the soft substrates, were characterized by a paucity of species and individuals. The similarity classification analyses showed two groups: one characterized by having 61 species in common and high richness with 113 exclusive species. The other group with low diversity and richness values, 37 species in common and 23 exclusive species.
\end{abstract}

\section{Introduction}

Four main estuarine types are recognized: drowned river valleys (coastal plain estuaries), lagoons (sand bar or barrier island estuaries), fjords (glaciers originated estuaries), and tectonic estuaries $[1,2]$. The latter is caused by tectonic processes such as faulting, gravels formation, landslide, volcanic eruption, and marine erosion. Drowned river valleys and lagoons are characterized by soft substrates, mud or sand bottoms, while tectonic estuaries present higher diversity of substrates, including rocky shores, and cliffs, and consequently more coastal ecosystems. These ecosystems are comprised of a high variety of habitats with different types of substrate, bottom topography and sediment types, presence of vegetation cover and biogenic structures, resulting from erosion processes, river fluxes, and mangrove leaves decomposition.
As a result of the habitat diversity and its interaction with the environment, benthic (epi- and endobenthic) communities differ in taxonomic composition, specific abundance and functional role of organisms $[3,4]$. Knowledge of the abundance patterns and taxonomic composition of the benthic communities and their trophic relationships is important to reveal their functional role [5]. The main factors that influence the composition of the benthic communities are amount and size of substrate particles, sedimentation rate, amount of organic matter, and upwelling currents. In the coastal zones, variations of salinity, temperature, and dissolved oxygen in the water-sediment interface are also important.

Benthic organisms are used as indicators of oceanographic conditions and abnormal deposits, as well as of natural and/or anthropogenic disruptions and are occasionally used to monitor and evaluate conservation programs in some 
parts of the world [6-8]. In the eastern tropical Pacific, these communities have mainly been studied in Costa Rica $[9,10]$, Perú $[11,12]$, and Chile [7, 13, 14].

Despite the importance of benthic communities, and the high diversity of habitats available for them in tectonic estuaries, macrobenthic assemblages associated to this type of estuary have received less attention, compared with other estuaries such as fjords and coastal plains or other coastal ecosystems such as rocky shores or coral reefs. There are few exceptions, for example, San Francisco Bay (USA) where benthic communities have been studied intensively in relation to pollution [15-18]). In tropical zones, the only tectonic estuary relatively well studied for benthic assemblages is the Gulf of Nicoya in Costa Rica [9, 10, 19, 20].

In the Tropical Eastern Pacific estuaries and the Colombian Pacific coast, most of the studies on distribution patterns and abundance of species have been focused on mangrove benthic communities and other intertidal ecosystems such as sandy beaches, muddy flats, mangroves, and rocky cliffs and shores $[8,21-26]$.

For submerged bottom communities, the few studies performed have been carried out in the coastal plain estuary of Buenaventura $[8,27]$ and submerged bottoms of sand, mud, rocks, and coral reefs of Gorgona Island [28]. Little is known about the macrobenthic fauna of tectonic estuaries and even less is known about the sublittoral fauna. The main purpose of this investigation was to determine the taxonomic composition, distribution, and abundance patterns of the species inhabiting a tectonic estuary in relation to other types of estuaries. The questions examined were (1) what is the assemblage structure of the submerged hard and soft bottom macrofauna in Bahía Málaga, an important tectonic [29] estuary of the Pacific coast of Colombia? (2) Are these assemblages different from the benthic macrofauna of other tectonic estuaries or from other types of estuaries of the Tropical Eastern Pacific? (3) How do the assemblages vary in relation to the differences in substrates and water environmental variables, following the estuarine gradients? (4) How are benthic assemblages of Málaga Bay compared with other estuaries of the world?

\section{Materials and Methods}

2.1. Study Area. This research was conducted in Bahia Málaga $\left(4^{\circ} 05^{\prime} \mathrm{N}\right.$ and $\left.77^{\circ} 16^{\prime} \mathrm{W}\right)$, a tectonic estuary located on the Pacific coast of Colombia (Figure 1). The bay has a length of approximately $25 \mathrm{~km}$ and an area of $136 \mathrm{~km}^{2}$ and is surrounded by rocky cliffs. The tidal current flux is ca. $20000 \mathrm{~m}^{3} \mathrm{~s}^{-1}$ between the bay and the open ocean [30]. The north border is marked by a geological fault (Málaga Fault) and the southern border is limited by the uplifting of Pichido Isthmus. At present, there are important erosive processes along all borders of the bay. These processes are mainly cliff erosion in the internal border of the bay with the fall of rocks caused by hydraulic action, wave pounding, bioerosión, and beach erosion in the external border by wave action.

The external border is composed of shallow sandy zones and rocky islands. The internal region has shallow bottoms and rocky islands surrounded by muddy flats. The bay has two channels, one with hard substrate and average depths of around $15 \mathrm{~m}$ (maximum approximately $40 \mathrm{~m}$ ), and the other with soft sediments and depths near $5 \mathrm{~m}$. These channels converge in the narrow part of the bay, increasing the speed of the tidal current, which reaches up to $2.0 \mathrm{~m} \mathrm{~s}^{-1}$ [3032]. Water temperatures range from 24 to $30^{\circ} \mathrm{C}$. The bay is subjected to a relatively large semidiurnal tidal range (macrotidal, ca. $4 \mathrm{~m}$ ) which affects both salinity and depth $[33,34]$. Despite the high rainfall (Bahía Málaga is located near to one of the most humid low land places in the world), there are few rivers, and consequently, the fresh water input is low compared to most estuaries of the Pacific coast of Colombia. Climatic conditions vary from less humid (dry) in June-July and December-January to more humid (rainy) in February-May and from September to November [35].

Bahía Málaga contains many of the habitats and marine life zones of the Pacific coast of Colombia [8] (Figure 1). The western external zone of the bay is surrounded by sandy beaches (Juanchaco and Ladrilleros) formed by the accumulation of sand of continental origin that is transported by rivers and marine hydrodynamic processes. The southern and central regions have borders constituted by consolidated sediments (mudstones, siltstones) of Tertiary origin, giving the bay a rocky appearance, with dense forests and large trees. The rocky coasts generally form high cliffs, sometimes separated by the sea, or by rocky, sandy, or muddy beaches between tides. Inside the bay, several small rocky islands are found, which were separated from the mainland by erosion (e.g., Isla Palma, Los Monos, and Curichichi) and by emersion (La Plata) [29].

2.2. Sampling and Data Analysis. Sampling was conducted for 14 months, in the following localities: Los Negritos (St. 1), Isla Palma (St. 2), and La Barra (St. 3) in the external part of the bay; Los Negros (St. 4), Los Monos (St. 5), Curichichi island (St. 6), Mayordomo (St. 7), and La Plata island (St. 8) in the internal part (Table 1). All samples, from hard and soft bottoms, were taken from depths between 2 and $10 \mathrm{~m}$ (Figure 1).

Due to some of the features of the bay (e.g., high sedimentation, mixed bottoms of hard and soft substrates, and turbid waters) and the paucity of benthic species which are distributed in patches, it is very difficult to use only one sampling method (transects in scuba diving or dredges) to obtain a global and true vision of the biodiversity of the zone. Hence, it was necessary to combine several sampling techniques. Some localities (Sts. 1, 2, 5, 6, 7, 8) were sampled using transects (30 m length) surveyed by snorkeling and scuba diving. The transects were marked by a line and the sampling was conducted on both sides, surveying two meters to each side. Along each transect $(30 \times 4 \mathrm{~m})$, all organisms were collected. All transects had two replicates. Others (Sts. 3 and 4) were sampled with a "change" (artisanal bottom trawling net used by local fishermen). Since the net was damaged by the rugged bottom, it was possible to take only a few samples. Additionally, we used a Petersen dredge of $0.05 \mathrm{~m}^{2}$ $(2500 \mathrm{~mL})$ for sampling the sediments and endobenthic 


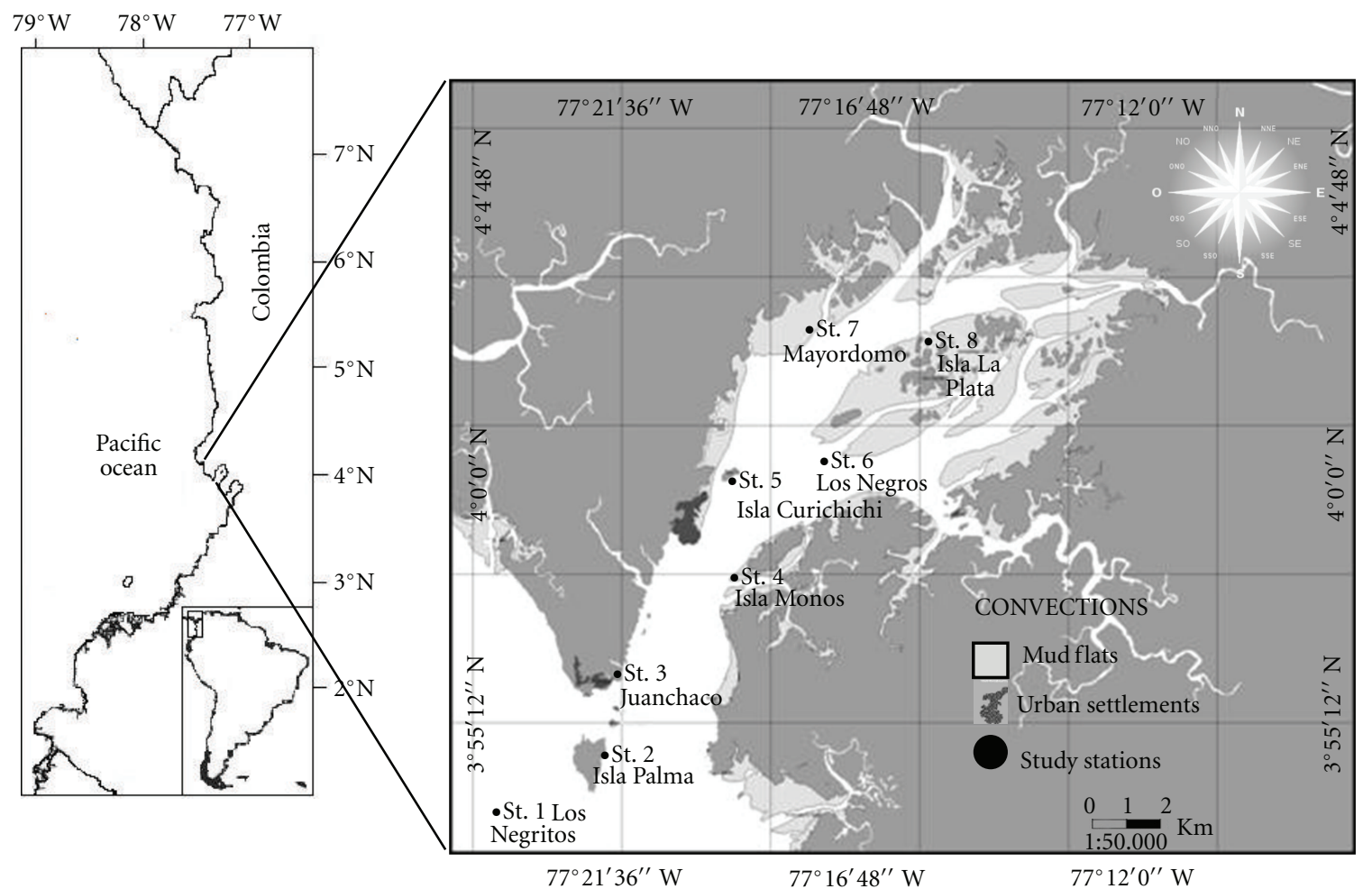

Figure 1: Study area: Bahia Málaga, Pacific coast of Colombia, the black dots correspond to the sampling stations.

TABLE 1: Geographical localization, abbreviations, and average depth of studied stations.

\begin{tabular}{|c|c|c|c|c|c|}
\hline ID & Locality & Abbreviation & Depth $(\mathrm{m})$ & Latitude $\mathrm{N}$ & Longitude W \\
\hline St. 1 & Los Negritos & LNE & 3.5 & $3^{\circ} 53^{\prime}$ & $77^{\circ} 24^{\prime}$ \\
\hline St. 2 & Isla Palma-Morro Chiquito & IPM & 3.7 & $3^{\circ} 54^{\prime}$ & $77^{\circ} 21^{\prime}$ \\
\hline St. 3 & La Barra-Juanchaco & BJL & 3.4 & $4^{\circ} 01^{\prime}$ & $77^{\circ} 28^{\prime}$ \\
\hline St. 4 & Isla Monos & MON & 8.7 & $3^{\circ} 58^{\prime}$ & $77^{\circ} 28^{\prime}$ \\
\hline St. 5 & Los Negros & LNG & 2.7 & $3^{\circ} 59^{\prime}$ & $77^{\circ} 17^{\prime}$ \\
\hline St. 6 & Isla Curichichi & $\mathrm{CHI}$ & 2.8 & $3^{\circ} 59^{\prime}$ & $77^{\circ} 19^{\prime}$ \\
\hline St. 7 & Mayordomo & MAY & 3.2 & $4^{\circ} 01^{\prime}$ & $77^{\circ} 18^{\prime}$ \\
\hline St. 8 & Isla La Plata_-Isla Grande & ARP & 2.9 & $4^{\circ} 03^{\prime}$ & $77^{\circ} 15^{\prime}$ \\
\hline
\end{tabular}

fauna of soft bottoms. For the different sampling gear used in the study, we will use the term assemblages when referring to our study.

Salinity, dissolved oxygen, conductivity, temperature, and $\mathrm{pH}$ were used to evaluate the physicochemical parameters of the water column. For the sediment analysis, the procedure of sifting based on the Wentworth scale [36] was employed, in which the sediments were dried at air temperature. The results were shown in percentages for each particle size. The samples were then heated to $100^{\circ} \mathrm{C}$ to reach a constant weight for the calculation of organic matter.

The biological samples were fixed in situ with $10 \%$ neutralized formalin. Next, the macrobenthos was separated using a $0.5 \mathrm{~mm}$ mesh sieve $[36,37]$ identified, and the number of individuals in the total area was determined. Finally, the organisms were preserved in $70 \%$ alcohol or $10 \%$ buffered formalin (depending on the taxonomic group) and placed in the reference collection of the Universidad del ValleCRBMUV "Univalle," the Museo de Ciencias Naturales del Departamento del Valle-IMCN "Inciva," and the Museo de Historia Natural Marina de Colombia-MHNMC "Invemar."

The obtained data were arranged in matrices of abundance for each species (individual numbers per sampled area, $0.10 \mathrm{~m}^{2}$ ) for each locality and then compared with the other localities. The spatial distribution pattern of the community was estimated according to presence-absence data of species (due to the high species richness, low species abundance, patchiness in the distribution, and different types of sampling). The relationship between localities was studied using a hierarchical agglomerate clustering technique (cluster analysis) and unweighted pair group average linking method (UPGMA) [38] using the Bray-Curtis similarity index [39]. Ordination using nonmetric multidimensional scaling analysis (nMDS) was performed to determine the variation of 
species composition [40] and confirm the groups formed by the cluster. Then, a superimposed analysis was done using nMDS, to find the relationship within the group with the physicochemical parameters [41]. Finally, a modification of inverse analysis was utilized to find, by composition and relative frequency, the key species in each group and to determine which of these species were exclusive or generalist [42]. The results were analyzed including abiotic variables (sediments and water conditions) for each locality. Multivariate analysis was applied for the assemblage structure with PRIMER software (plymouth routines in multivariate ecological research).

\section{Results}

\subsection{Environmental Variables}

3.1.1. Physicochemical Parameters. The four physicochemical variables of the water column (temperature, salinity, $\mathrm{pH}$, and dissolved oxygen) showed weak gradients along the bay. Highest average values of temperature and salinity were found at St. 1, showing the effects of tropical marine waters on the external zones. The lowest values for temperature and salinity were found at St. 7 and for $\mathrm{pH}$ and dissolved oxygen at St. 4 (Table 2). The average surface water temperature in all localities varied between 26.8 and $30.6^{\circ} \mathrm{C}$. The average salinity is higher than 20 (in practical unities of salinity) along the bay at high tide as well as low tide, except in two stations of the inner part: St. 8 and St. 4. The low salinity at low tide is due to fresh water inputs by inner creeks in St. 8 and of the La Sierpe River in St. 4. The external part (St. 3) is also affected by fresh water inputs, at times when the San Juan River discharge arriving by the northern part causes important decreases in salinity. The highest values of dissolved oxygen were found at Sts. 2, 3, and $6(>7.0 \mathrm{mg} / \mathrm{L}$ in high tide). In the other stations, values were uniform along the bay and throughout the time of study.

3.1.2. Sediment Composition. Submerged bottoms are very heterogeneous in Bahía Málaga; the external zone contains sandy substrates, enriched by muddy material or detritus originated from mangrove decomposition (St. 3) and rocky substrates forming islands or submerged reefs (Sts. 1, 2). The internal zone has mainly muddy substrate, with detritus coming from decomposition of continental mangroves (Sts. $7,5)$ and submerged and intertidal rocks originated by erosion (Sts. 5, 6, 8) near to emerged islands and/or independent accumulation of rocks together with mud in the central part of the bay (St. 4, 5, 6) (Figure 2).

Sediment analysis showed that bottoms with coarse particles (gravel, coarse sand) are found mainly in St. 1, 2, 5, 6 and 8, soft bottoms with fine sands in St. 3 and 7 and slime and clays in St. 7 and 8 (Figure 3). Coarse sand is very abundant in St. 1, gravel in St. 6, fine sand in St. 3, and lime and clay in St. 4. Organic matter values of the sediments range between 0.2 and $4.4 \%$, with the highest in St. 8 and lowest in St. 7. Selection factor of sediment particles are variable (Table 3 ).
TABLe 2: Physicochemical parameters for each locality in Bahia Malaga estuary from May 2006 to May 2007.

\begin{tabular}{lcccc}
\hline Station & $\begin{array}{c}\text { Temperature } \\
\left({ }^{\circ} \mathrm{C}\right)\end{array}$ & Salinity & $\begin{array}{c}\text { Dissolved oxygen } \\
(\mathrm{mg} / \mathrm{L})\end{array}$ & $\mathrm{pH}$ \\
\hline St. 1 & $29.7-31.5$ & $25.0-28.0$ & $6.6-7.2$ & $8.3-8.4$ \\
St. 2 & $28.0-28.6$ & $21.6-27.0$ & $6.4-7.1$ & $8.2-8.3$ \\
St. 3 & $27.2-28.2$ & $15.3-23.4$ & $6.3-7.5$ & $8.1-8.1$ \\
St. 4 & $28.7-30.1$ & $17.0-24.8$ & $6.4-6.3$ & $7.7-8.2$ \\
St. 5 & $28.7-29.1$ & $21.6-25.8$ & $6.3-6.7$ & $8.0-8.3$ \\
St. 6 & $28.5-29.0$ & $22.4-27.7$ & $6.2-7.3$ & $8.0-8.4$ \\
St. 7 & $26.8-28.5$ & $20.6-22.1$ & $6.5-6.6$ & $8.0-8.2$ \\
St. 8 & $28.8-30.4$ & $18.6-24.1$ & $6.0-7.0$ & $7.8-8.1$ \\
\hline
\end{tabular}

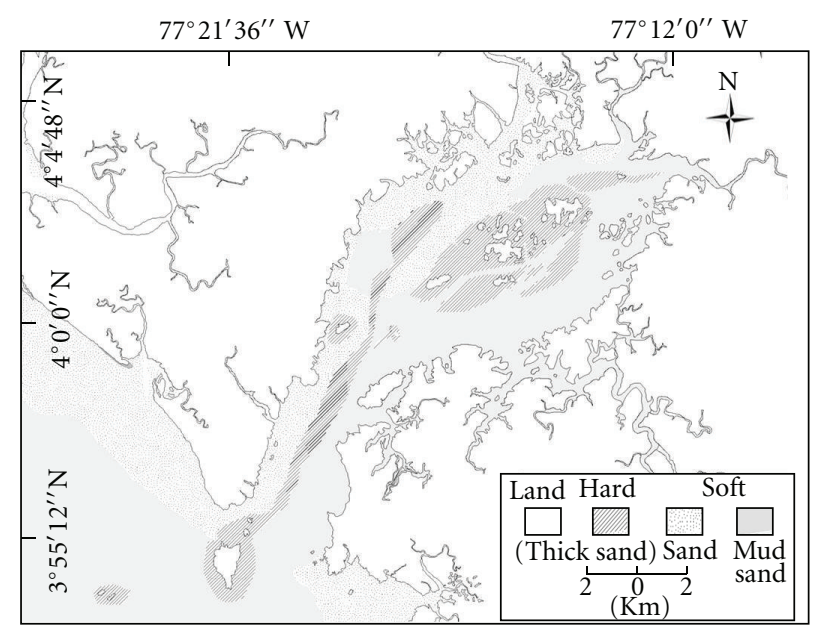

FIGURE 2: Distribution of substrate types in submerged bottoms of Bahía Malaga estuary.

\subsection{Assemblages Analysis}

3.2.1. Taxonomic Characterization. A total of 728 individuals from 207 species, 132 genera, 86 families, and 14 orders of six taxa of invertebrates (Table 5) were obtained in both, soft and hard bottom samples (Table 4). Mollusca dominated in number of species comprising 66\% (137 spp.) of the macrofauna, crustaceans constituted 19\% (39 spp.), Echinodermata 9\% (19spp.), Polychaeta 3\% (6 spp.), Porifera 2\% (4spp.), and Cnidaria 1\% (2spp.). The localities that presented the highest number of species were St. 1 (28\% of the species), St. 4 (18\%), St. 6 (13\%), and St. 2 (15\%). The low number of species and individual polychaetes in relation to mollusks could be explained by the presence of hard substrates of different sizes mixed with the mud and sand in this tectonic estuary. These hard substrates are suitable habitat for some species of gastropods.

In terms of relative specific abundance, the organisms were comprised of mollusks (56\%, 407 individuals), crustaceans $(15 \%, 109)$, echinoderms $(13 \%)$, corals $(9 \%)$, sponges (5\%), and polychaetes (2\%). The most abundant groups of species were: Acanthais brevidentata, Cardita affinis, Crepidula aculeata, Natica unifasciata, Nemocardium sp., 


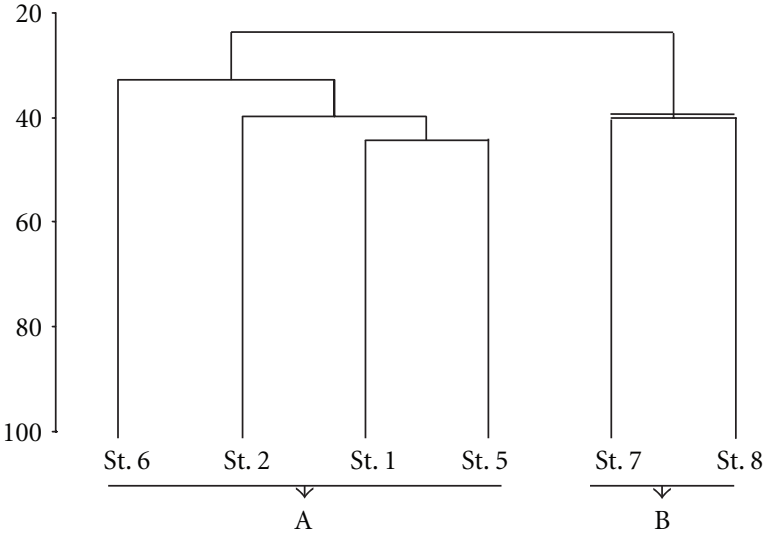

(a)

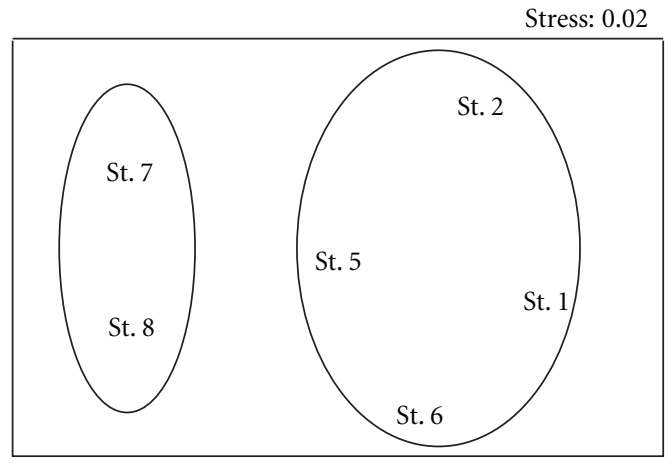

(b)

FIGURE 3: Classification and ordination analysis of studied stations made from absence-presence data of species matrix for the studied stations in Bahia Malaga estuary: (a) Bray-Curtis similarity dendrogram and (b) nMDS ordination (stress value $<0.02$ ).

Table 3: Particle size distribution (\%), organic matter (\%), and particle selection factor of sediments of the stations of Bahia Malaga estuary.

\begin{tabular}{lcccccccc}
\hline \multirow{2}{*}{ Particle type } & \multicolumn{8}{c}{ Station } \\
& St. 1 & St. 2 & St. 3 & St. 4 & St. 5 & St. 6 & St. 7 & St. 8 \\
\hline Gravel & 26.5 & 28.6 & 0 & 0.9 & 29.4 & 32.2 & 0 & 24.8 \\
Very coarse sand & 6.1 & 16.5 & 0 & 3.2 & 35.2 & 20.8 & 0 & 23.7 \\
Coarse sand & 40.6 & 24.1 & 0.8 & 5.0 & 25.5 & 29.5 & 6.0 & 32.0 \\
Middle sand & 19.0 & 18.7 & 26.4 & 6.3 & 4.6 & 12.9 & 3.9 & 9.2 \\
Fine sand & 7.5 & 6.8 & 72.5 & 62.7 & 4.0 & 1.5 & 79.2 & 6.6 \\
Slime and clay & 0.2 & 3.1 & 0.2 & 21.1 & 1.0 & 0.8 & 8.4 & 3.4 \\
Organic Matter & 3.8 & 3.2 & 1.4 & 1.9 & 3.4 & 4.3 & 0.2 & 4.4 \\
Particle Selection & 1.4 & 1.5 & 0.7 & 0.7 & 0.6 & 1.1 & 0.5 & 1.0 \\
\hline
\end{tabular}

Nerita funiculata, Petaloconchus complicates, and Zonaria robertsi; (Mollusca); Alpheus cylindricus, A. formosus, Hepatus kossmanni, Pachycheles panamensis, Petrolisthes edwardsii, P. galathinus, and P. haigae; (Crustacea); Echinometra vanbrunti, Hesperocidaris asteriscus, Holothuria impatiens, Ophiocoma aethiops, Ophioderma panamensis, Ophionereis annulata, Ophiotrix spiculata, Pharia pyramidata, and Phataria unifascialis (Echinodermata): Eunice sp. and Platynereis sp. (Polychaeta); Leptogorgia alba and Pacifigorgia eximia (Cnidaria) and Aplysina (or Verongia) sp. (Porifera). The most common species (being present in $40 \%$ or more of the samples) were Mollusca: Cardita affinis, Thais melones, Natica unifasciata, and Nerita funiculata; Crustacea: Alpheus wickstenae, Petrolisthes nobilii, P. armatus, Panopeus chilensis, Panopeus purpureus, and Clibanarius panamensis; Cnidaria: Leptogorgia alba and Pacifigorgia eximia; and Porifera: Aplysina sp.

3.2.2. Spatial Distribution Patterns. The two localities sampled with fishing nets (Sts. 3 and 4) were neither included in the nMDS analysis nor in the cluster analysis because of differences in the sampled areas, capture time, frequency of sampling, and bottom composition (fine sand and/or slime and clays in Sts. 3 and 4 versus gravel and coarse sand in other localities). After the cluster analysis, the other six localities can be separated into two groups (Figure 3): Group A contains four localities with more than $40 \%$ similarity, two located outside the bay (Sts. 1 and 2) and two on the inside with little more than $40 \%$ similarity (Sts. 5 and 6), with high richness (between 45 and 92 species); the four stations shared 61 species; Group $B$ containing two localities with $40 \%$ similarity (Sts. 7 and 8 ), in inner parts of the bay, these stations were characterized by low richness (between 23 and 57 species) and they shared 37 species. The inverse analysis (Table 5) presents 113 exclusive species for Group A, 23 species for Group B, and 41 frequent species. The most frequent species were Bursa corrugata, Cantharus ringens, Zonaria robertsi, and Macrocypraea cervinetta in Group A; Corbula biradiata in Group B.

3.3. Relation between the Assemblages and Environmental Variables. The environmental variables superimposed on the nMDS revealed that the sediment characteristics are the most important parameters determining assemblage structure of macrobenthos of Bahía Málaga. Group A (Sts. 1, 2, 5, 6) displays high values for hard or thick sediments (gravel and coarse sand), while Group B displays mixed soft bottoms: fine sand, slime and clay in St. 7 and slime and clay mixed with gravel in St. 8. In addition, Group A shows high values for organic matter and the particle selection coefficient with respect to the other localities (Table 2 ). The physicochemical parameters of water (temperature, dissolved oxygen, and $\mathrm{pH}$ ) do not have a strong influence on the groups, although the values of salinity for Group A are slightly greater than those for Group B (Figure 4).

\section{Discussion}

This study evaluates the invertebrate (macrofauna) assemblage structure of the submerged bottoms of a tectonic estuary: Bahía Málaga in relation to several physicochemical characteristics. Since this is a macrotidal estuary, intertidal areas are wide, and they have been well studied. The first observation about this estuary is the unusually high species 
TABLE 4: Number of species and families (parenthesis) of taxonomic groups in the sampled localities of Bahia Malaga estuary.

\begin{tabular}{|c|c|c|c|c|c|c|c|c|}
\hline Taxa & St.1 & St. 2 & St. 3 & St. 4 & St. 5 & St. 6 & St. 7 & St. 8 \\
\hline Crustacea & $13(9)$ & $19(14)$ & $8(7)$ & $2(2)$ & $6(6)$ & $10(8)$ & $3(3)$ & $4(2)$ \\
\hline Mollusca & $40(28)$ & $20(13)$ & $13(12)$ & $11(10)$ & $23(13)$ & $28(23)$ & $39(23)$ & $3(2)$ \\
\hline Polychaeta & $4(4)$ & 1 & 0 & 1 & 0 & $5(5)$ & $3(3)$ & 0 \\
\hline Echinodermata & $10(8)$ & $3(3)$ & 1 & 1 & $4(4)$ & $2(2)$ & $2(2)$ & 1 \\
\hline Cnidaria & $2(2)$ & 1 & $2(2)$ & 0 & 1 & 1 & 1 & 0 \\
\hline Porifera & 0 & 1 & 0 & 0 & $2(2)$ & 1 & 1 & 0 \\
\hline
\end{tabular}

richness compared to the coastal plain estuaries of this area (625 species of macroinvertebrates [31], 207 present in submerged substrates) in relation to 126 in the estuary of Buenaventura Bay [27], 78 in the Dagua River estuary [26] and 36 in the San Juan river [43], which are located near Bahía Malaga. As was shown by Gray [44] worldwide, by Guzmán-Alvis et al. [45] for the Caribbean coast of Colombia and by Cortés [25] and Cantera [8] for other zones of the Pacific coast of Colombia, the most important factors determining the structure of these tropical benthic assemblages are sedimentological variables. The particularly high species richness of the submerged bottoms of this estuary can be explained by two factors: (1) the predominance of hard substrates such as rocks, gravel and coarse sand, where there are 151 species, of which 113 are exclusive (70 molluscs, 24 crustaceans 14 echinoderms, 4 polychaetes and 1 sponge); (2) the relatively high salinity. Both conditions are not common in Tropical Pacific estuaries. Species richness is lower in areas with predominance of soft bottoms (fine sand, slime, and clays) and low salinities, where only 57 species were found, of which 23 were unique $(20$ mollusks, 2 crustaceans, and 1 soft coral). Both conditions (hard substrate and high salinity) are infrequent in most estuaries of the Pacific coast of Colombia and other regions of the Tropical Eastern Pacific, because the high precipitation in the zone (more of $6000 \mathrm{~mm} \mathrm{yr}^{-1}$ ) causes high sedimentation and lower salinity.

The localities in Bahía Málaga with a greater percentage of soft bottoms are structurally more homogeneous and contain less diversity, while the ones with greater variety in the size of the sediment particles have a structurally heterogeneous habitat and therefore more diversity. The composition and selection of bay sediments are related to the patterns of current circulation. In the internal region of Bahia Málaga, high percentages of fine sand, slime, and clay are accumulated due to weaker tidal currents, at the same time the effect of freshwater is greater. In the external localities of the bay (and in the islands located in the Central channel), there are hard bottoms with abundant boulders, gravel, and coarse sand. Fine sediments are absent mainly due to the influence of tidal currents and stronger swells. The values of organic matter in the sediments are similar to previous studies in these zones [8] and to previously reported values in tropical zones [46]; nevertheless, the high levels found in this study in some areas can be explained by the sediments contributed by the micro-upwellings in the estuary [21] and by areas adjacent to river discharge [47].
Variables of sea water, usually very important in estuarine environments especially in coastal plain estuaries, have minor importance in the distribution of macrobenthic assemblages of the tectonic estuary of Bahía Málaga. Some of these conditions (e.g., temperature, dissolved oxygen, and $\mathrm{pH}$ ) are strongly variable due to tidal changes, high turbidity, high organic decomposition, and freshwater input as is the case in the majority of the Pacific estuaries of Colombia, in which differences in processes and conditions exist in different times during the day or in different seasons, allowing a wide range of physiologically adaptive macrofaunal species to live there [21]. In this way, the distribution of benthic assemblages is influenced only by salinity where substrate conditions are very similar (e.g., organisms highly dependent on seawater, such as echinoderms and gorgonians, are more abundant in St. 1, with salinity between 25 and 28 than in St. 5, with salinity between 21 and 25). These groups are completely absent in stations with salinity values lower than 20 (Sts. 7 and 8) in the daily variations and high sedimentation rate. As the bay is a complex estuary, with inputs of freshwater in different parts, not only in the inner regions, the parameters are not of equal magnitude in the different sectors of the bay, and therefore, fluctuations over short periods of time affect the spatial distribution of organisms in patches; that is why they do not follow the classic gradient found in other types of estuaries with marine fauna in the external parts of the bay and freshwater fauna in the inner zones [48]. In a few particular cases, some of the variables become significant; for instance, the high temperature (nearly $29^{\circ} \mathrm{C}$ ) and the low oxygen concentration (less of $4 \mathrm{mg} \mathrm{L}^{-1}$ ) reached at the surface of muddy plains during low tides in shallow zones, can be related to the very low diversity and abundance of species in the internal localities of the estuary. The shape and bathymetry of the bay also cause fluctuations in the sediment structure, because there are different velocities of currents, with some zones exposed to strong currents in two channels at both sides of the bay, causing erosion, and some sedimentation zones with low currents in the central area of the bay and at the border where mangroves are abundant. These fluctuations have been observed also in other estuaries of the world, for example, in the Sao Sebastian Chanel in Brazil, San Francisco Bay where the variation in the types of sediment determines changes in the physical-chemical variables of the zones, giving important and indirect causes in the patterns of community establishment [47]. 
TABle 5: *Exclusive species of Group A. **Exclusive species of Group B. ***Frequent species of Groups A-B.

\begin{tabular}{|c|c|c|c|c|c|c|c|c|}
\hline Localities/species & LNE & LNG & $\mathrm{CHI}$ & MAY & MON & IPM & $\mathrm{BJL}$ & ARP \\
\hline \multicolumn{9}{|l|}{ PORIFERA } \\
\hline Placospongia carinata* & 1 & 1 & 1 & & & & & \\
\hline Verongia sp.*** & & 1 & 1 & 1 & & & & 1 \\
\hline \multicolumn{9}{|l|}{ CNIDARIA } \\
\hline Leptogorgia alba*** & 1 & 1 & 1 & 1 & & 1 & & 1 \\
\hline Pacifigorgia eximia*** & 1 & 1 & 1 & 1 & & & & \\
\hline Tubastrea coccinea & & & & & & & 1 & \\
\hline Renilla sp.** & & & & 1 & & & 1 & \\
\hline \multicolumn{9}{|l|}{ POLYCHAETA } \\
\hline Eunice sp.*** & & & 1 & 1 & & & & \\
\hline Platynereis sp. ${ }^{* * *}$ & & & 1 & 1 & & & & \\
\hline Sabella sp.* & & & 1 & & & & & \\
\hline Notomastus sp.* & & & 1 & & & & & \\
\hline Megalomma sp.* & & & 1 & & & & & \\
\hline Palolo sp.* & & & & & & 1 & & \\
\hline \multicolumn{9}{|l|}{ MOLLUSCA } \\
\hline Acirsa murrha* & & 1 & & & & & & \\
\hline Acanthais brevidentata*** & 1 & & 1 & & & & 1 & 1 \\
\hline Acteocina sp. & & & & & 1 & & & \\
\hline Anachis sp.* & & & & & & 1 & & \\
\hline Anachis pygmaea* & & & 1 & & & & & \\
\hline Anadara Formosa & & & & & & & 1 & \\
\hline Arca mutabilis* & 1 & & & & & & & \\
\hline Barbatia reevana* & & 1 & 1 & & & & & \\
\hline Bulla gouldiana* & 1 & & 1 & & & & & \\
\hline Bulla punctulata* & & & 1 & & & & & \\
\hline Bursa corrugata* & 1 & 1 & 1 & & & 1 & 1 & \\
\hline Bursa nana & & & & & & & 1 & \\
\hline Caecum undatum* & 1 & & & & & & & \\
\hline Caecum sp.*** & & & 1 & 1 & & & & \\
\hline Cantharus sp.** & & & & 1 & & & & \\
\hline Cantharus elegans* & & & & & & 1 & & \\
\hline Cantharus ringens* & 1 & 1 & 1 & & & 1 & 1 & \\
\hline Cantharus sanguinolentus* & 1 & & & & & 1 & & \\
\hline Cardita affinis ${ }^{* * *}$ & & 1 & 1 & 1 & & 1 & 1 & \\
\hline Cardita spurca beebei** & & & & 1 & & & & \\
\hline Cardita radiata* & & 1 & 1 & & & & 1 & \\
\hline Cardita sp. & & & & & 1 & & & \\
\hline Cassis centiquadrata* & 1 & & & & & & & \\
\hline Cheilea cepacea*** & & & 1 & 1 & & & & \\
\hline Cheilea corrugata** $^{* *}$ & & & & 1 & & & & \\
\hline Chione amathusia* & & & 1 & & & & 1 & \\
\hline Chione compta* & 1 & & & & & & & \\
\hline Chione gnidia* & & 1 & & & & & & \\
\hline Chione subimbricata* & & 1 & & & & 1 & & \\
\hline Chione subrugosa*** & & & 1 & 1 & & & & 1 \\
\hline Cerithium adustum* & 1 & & & & & & & \\
\hline Clementia solida** & & & & & 1 & & & 1 \\
\hline Crepidula aculeata*** & & & 1 & 1 & & & 1 & 1 \\
\hline Crepidula striolata** & & & & 1 & & & & \\
\hline Crucibulum scutellatum* & 1 & 1 & & & & & & \\
\hline Crucibulum spinosum ${ }^{* * *}$ & & & 1 & 1 & & 1 & & \\
\hline
\end{tabular}


Table 5: Continued.

\begin{tabular}{|c|c|c|c|c|c|c|c|c|}
\hline Localities/species & LNE & LNG & $\mathrm{CHI}$ & MAY & $\mathrm{MON}$ & IPM & BJL & $\mathrm{ARP}$ \\
\hline Crucibulum personatum ${ }^{* * *}$ & & & 1 & 1 & & & & \\
\hline Columbella strombiformis* & 1 & & & & & 1 & & \\
\hline Conus patricius & & & & & & & 1 & \\
\hline Corbula biradiata** & & & & 1 & & & & 1 \\
\hline Corbula sp. & & & & & 1 & & & \\
\hline Cyclinella sacata & & & & & 1 & & & \\
\hline Cymatium vestitum & & & & & & & 1 & \\
\hline Cypraea arabicula* & 1 & & 1 & & & & & \\
\hline Diodora inaequalis* & & & 1 & & & & & \\
\hline Diodora pica* & 1 & & & & & & & \\
\hline Donax carinatus $* * *$ & & & 1 & 1 & & & & \\
\hline Dosinia sp.* & & & 1 & & & & & \\
\hline Ficus ventricosa & & & & & & & 1 & \\
\hline Fissurella sp.* & & 1 & & & & & & \\
\hline Fissurella sp. $2^{*}$ & & & 1 & & & & & \\
\hline Fissurella longifissa** & & & & 1 & & & & \\
\hline Fissurella virescens* & 1 & & 1 & & & 1 & 1 & \\
\hline Fissurella microtrema* & 1 & & 1 & & & & & \\
\hline Florimetis cognata** & & & & 1 & & & & \\
\hline Florimetis dombeii ${ }^{* *}$ & & & & 1 & & & & \\
\hline Glycymeris sp. ${ }^{* *}$ & & & & 1 & & & & \\
\hline Grandiarca grandis* & & 1 & & & 1 & & & \\
\hline Hindsiclava resina** & & & & 1 & & & & \\
\hline Hipponix grayanus* & 1 & & & & & & & \\
\hline Hipponix panamensis* & 1 & & 1 & & & & & \\
\hline Isognomon recognitus* & & & & & & 1 & & \\
\hline Latirus concentricus* & 1 & & & & & & & \\
\hline Latirus hemphilli* & & 1 & & & & & & \\
\hline Latirus mediamericanus* & 1 & 1 & 1 & & & & & \\
\hline Leptopecten tumbezensis* & & & & & & 1 & & \\
\hline Lithophaga plumula & & & & & & & 1 & \\
\hline Macrocallista sp. ${ }^{* * *}$ & & 1 & & 1 & & 1 & & \\
\hline Malea ringens* & & & 1 & & & & 1 & \\
\hline Megacypraea cervinetta* & 1 & 1 & 1 & & & 1 & & \\
\hline Megatella sp.** & & & & 1 & & & & \\
\hline Melongena patula* & 1 & & & & & & 1 & \\
\hline Mitra sp.* & & & 1 & & & & & \\
\hline Mitra lens* & 1 & & & & & & & \\
\hline Modulus disculus* & & & 1 & & & & & \\
\hline Muricanthu sradix ${ }^{* * *}$ & & 1 & 1 & 1 & 1 & & & \\
\hline Muricopsis zeteki* & 1 & 1 & & & & 1 & & \\
\hline Nassarius angulicostis* & & & 1 & & & & & \\
\hline Nassarius shaskyi & & & & & 1 & & & \\
\hline Natica broderipiana & & & & & 1 & & 1 & \\
\hline Natica chemnitzii & & & & & 1 & & 1 & \\
\hline Natica unifasciata*** & & 1 & 1 & 1 & 1 & & 1 & 1 \\
\hline Nemocardium sp. ${ }^{*}$ & & 1 & & & & & & \\
\hline Nerita funiculata*** & 1 & 1 & 1 & 1 & 1 & & 1 & 1 \\
\hline Northia pristis & & & & & & & 1 & \\
\hline Notoacmaea sp.* & 1 & & & & & & 1 & \\
\hline Oliva spendidula* & 1 & & & & & & & \\
\hline Opeatostoma pseudodon* & 1 & & & & & & & \\
\hline Papyridea aspersa* & 1 & & & & & 1 & & \\
\hline
\end{tabular}


Table 5: Continued.

\begin{tabular}{|c|c|c|c|c|c|c|c|c|}
\hline Localities/species & LNE & LNG & $\mathrm{CHI}$ & MAY & $\mathrm{MON}$ & IPM & $\mathrm{BJL}$ & $\mathrm{ARP}$ \\
\hline Papyridea mantaensis* & 1 & & & & & & & \\
\hline Pecten sp. ${ }^{*}$ & & & 1 & & & & & \\
\hline Pecten perulus* & & 1 & & & & & & \\
\hline Pecten vogdesi* & & 1 & & & & & & \\
\hline Petaloconchus innumerabilis** & & & & 1 & & & 1 & \\
\hline Petaloconchus complicatus*** & & 1 & 1 & 1 & & & 1 & \\
\hline Petricola exarata*** & & & 1 & 1 & & & & 1 \\
\hline Pholadidea esmeraldensis* & 1 & & & & & 1 & 1 & \\
\hline Pinctada mazatlanica*** & & 1 & & & 1 & & & 1 \\
\hline Pitar aequinoctalis* & & 1 & & & & & & \\
\hline Polinices uber* & & & 1 & & & & & \\
\hline Polystira nobilis & & & & & & & 1 & \\
\hline Protothaca ecuadoriana* & & 1 & & & & & & \\
\hline Psammotreta mazatlanica & & & & & 1 & & & \\
\hline Psammotreta viridotincta*** & & & 1 & 1 & & & & \\
\hline Pteria sp.*** & & 1 & & & 1 & & & 1 \\
\hline Semele sp.*** & & & 1 & 1 & & & & \\
\hline Scaphande cylindrellus** & & & & 1 & & & & \\
\hline Strigilla disjuncta** & & & & 1 & & & 1 & \\
\hline Strigilla chroma** & & & & 1 & & & 1 & \\
\hline Strombus galeatus* & 1 & 1 & & & & & & \\
\hline Tagelus affinis** & & & & 1 & 1 & & & \\
\hline Tellina sp.* & & & 1 & & & & 1 & \\
\hline Tellina subtrigona & & & & & 1 & & & \\
\hline Terebra robusta** & & & & 1 & & & 1 & \\
\hline Terebra glauca & & & & & 1 & & 1 & \\
\hline Thais biserialis* & 1 & & 1 & & & & 1 & \\
\hline Thais melones* & 1 & & 1 & & & & 1 & \\
\hline Thais speciosa* & 1 & & & & & & & \\
\hline Trachycardium pistipleura* & 1 & & 1 & & & & & \\
\hline Trachycardium senticosum ${ }^{* * *}$ & & 1 & 1 & 1 & & & & \\
\hline Trachycardium sp.* & & 1 & & & & & & \\
\hline Trigoniocardia biangulata** & & & & 1 & & & & \\
\hline Trigoniocardia guanacastensis*** & & & 1 & 1 & & 1 & & \\
\hline Trigoniocardia granifera* & & & 1 & & & & & \\
\hline Turbonilla sp.** & & & & 1 & & & & \\
\hline Turritella anactor* & & 1 & & & & & & \\
\hline Turritella leucostoma & & & & & 1 & & & \\
\hline Tripsycha tulipa* & & 1 & & & & & & \\
\hline Vermicularia pellucida*** & & & 1 & 1 & & 1 & & 1 \\
\hline Zonaria robertsi* & 1 & 1 & 1 & & & 1 & 1 & \\
\hline \multicolumn{9}{|l|}{ CRUSTACEA } \\
\hline Alpheus sp.* & & & 1 & & & & & \\
\hline Alpheus cylindricus* & 1 & & & & & & & \\
\hline Alpehus formosus* & 1 & & 1 & & & 1 & & \\
\hline Alpheus wickstenae ${ }^{* * *}$ & & & 1 & & 1 & 1 & & 1 \\
\hline Ambidexter panamensis*** & & 1 & & 1 & & & & \\
\hline Aniculus elegans* & 1 & & & & & & & \\
\hline Callinectes toxotes* & & & 1 & & & & 1 & \\
\hline Cleantioides vonprahli & & & & & & & 1 & \\
\hline Clibanarius panamensis ${ }^{* * *}$ & & & 1 & 1 & 1 & 1 & 1 & 1 \\
\hline Cycloxanthops vittatus* & 1 & & 1 & & & 1 & & \\
\hline Daldorfia garthi* & 1 & & & & & & & \\
\hline
\end{tabular}


Table 5: Continued.

\begin{tabular}{|c|c|c|c|c|c|c|c|c|}
\hline Localities/species & LNE & LNG & $\mathrm{CHI}$ & MAY & $\mathrm{MON}$ & IPM & BJL & $\mathrm{ARP}$ \\
\hline Dardanus sinistripes & & & & & & & 1 & \\
\hline Farfantepenaeus californiensis & & & & & 1 & & & \\
\hline Gonodactylidae sp.* & & & 1 & & & & & \\
\hline Hepatus kossmanni & & & & & & & 1 & \\
\hline Menippe frontalis* & 1 & & 1 & & & 1 & & \\
\hline Mithrax spinipes* & 1 & & & & & & & \\
\hline Pachycheles panamensis*** & & & & & & 1 & & 1 \\
\hline Panopeus chilensis*** & & 1 & 1 & 1 & 1 & & 1 & 1 \\
\hline Panopeus purpureus*** & & 1 & 1 & 1 & 1 & 1 & 1 & 1 \\
\hline Panulirus gracilis* & 1 & 1 & 1 & & & & 1 & \\
\hline Petrolisthes armatus*** & & 1 & 1 & 1 & 1 & & 1 & \\
\hline Petrolisthes nobilii*** & & 1 & 1 & 1 & 1 & 1 & & 1 \\
\hline Petrolisthes edwardsii*** & 1 & & 1 & 1 & & 1 & & \\
\hline Petrolisthes galathinus & & & 1 & & & 1 & & \\
\hline Petrolisthes glasselli* & & & & & & 1 & & \\
\hline Petrolisthes ortmanni* & 1 & & 1 & & & 1 & & \\
\hline Petrolisthes vicarius* & & & & & & 1 & & \\
\hline Petrolisthes haigae* & 1 & & & & & 1 & & \\
\hline Pilumnus sp.* & 1 & & 1 & & & 1 & & \\
\hline Pilumnus limosus* & & & 1 & & & & & \\
\hline Pilumnus nobili* & & 1 & 1 & & 1 & & & \\
\hline Pilumnus townsendi*** & & & 1 & 1 & & 1 & & \\
\hline Pinnotheres sp. ${ }^{* *}$ & & & & 1 & & & & \\
\hline Pisidia magdalenensis* & 1 & & 1 & & & 1 & & \\
\hline Podochela angulata* & & & 1 & & & & & \\
\hline Squillaaculeataaculeata*** & & & 1 & 1 & & & 1 & 1 \\
\hline Synalpheus nobilii*** & & & & & & 1 & & 1 \\
\hline Synalpheu stownsendi peruvianus*** & 1 & & & 1 & & & & 1 \\
\hline Trizopagurus sp. & & & & & & & 1 & \\
\hline Trizopagurus magnificus* & 1 & 1 & & & & 1 & & \\
\hline Typton serratus* & & 1 & 1 & & & & & \\
\hline Upogebia thistle* & 1 & & & & & & & \\
\hline \multicolumn{9}{|l|}{ ECHINODERMATA } \\
\hline Diadema mexicanum* & 1 & & & & & & & \\
\hline Echinometra vanbrunti* & 1 & 1 & & & & 1 & 1 & \\
\hline Encope sp.** & & & & 1 & & & & \\
\hline Hesperocidaris asteriscus* & 1 & & 1 & & & & & \\
\hline Holothuria hilla* & 1 & 1 & 1 & & & & & \\
\hline Holothuria impatiens* & 1 & & & & & & & \\
\hline Holothuria inhabilis* & 1 & 1 & 1 & & & & & \\
\hline Holothuria leucospilota* & 1 & 1 & 1 & & & & & \\
\hline Isostichopus fuscus* & 1 & & & & & & & \\
\hline Luidia superba & & & & & & & 1 & \\
\hline Ophiocoma sp. & & & & & 1 & & & \\
\hline Ophiocoma aethiops* & 1 & & 1 & & 1 & 1 & & \\
\hline Ophiocoma alexandri* & 1 & & & & 1 & & & \\
\hline Ophioderma panamensi* & 1 & & 1 & & & & & \\
\hline Ophionerei sannulata* & 1 & & 1 & & & 1 & & \\
\hline Ophiotrix spiculata*** & 1 & & 1 & 1 & & 1 & & 1 \\
\hline Pharia pyramidata* & 1 & & 1 & & & & & \\
\hline Phataria unifascialis* & 1 & 1 & 1 & & & & & \\
\hline
\end{tabular}




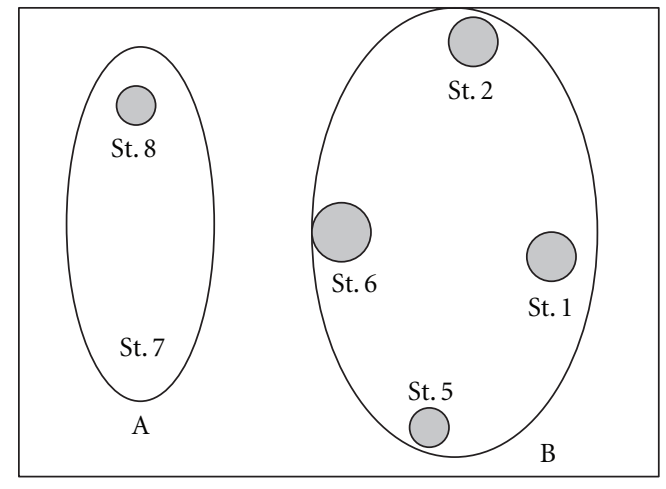

(a)

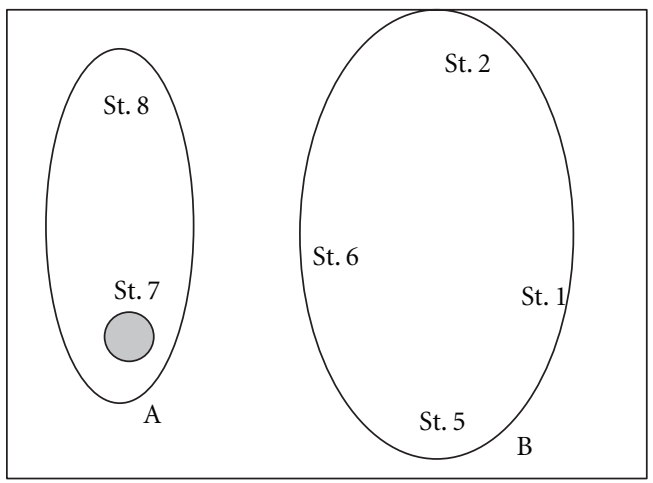

(c)

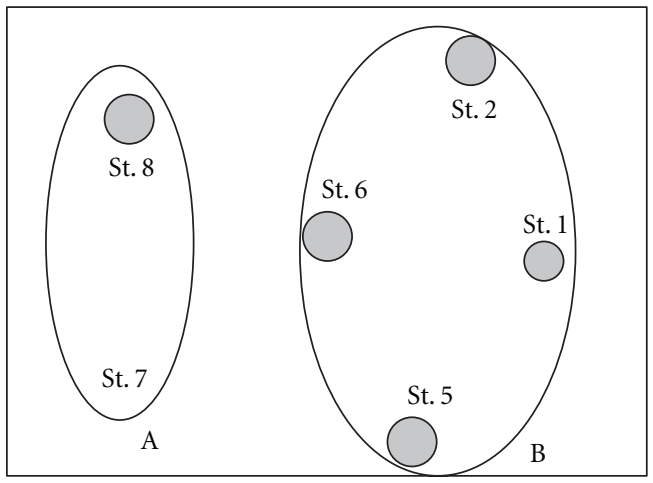

(e)

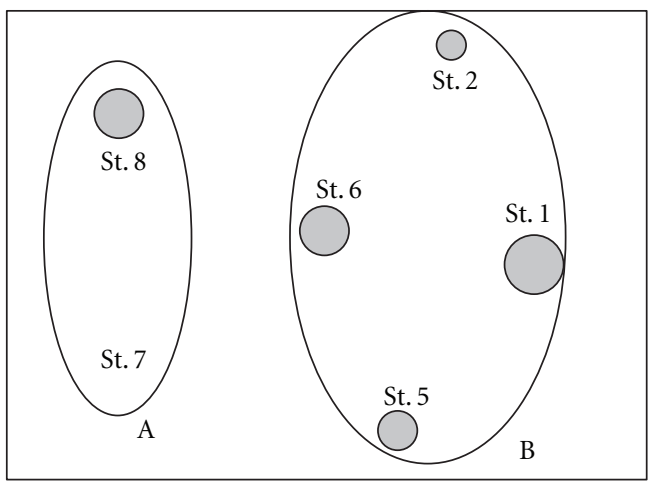

(b)

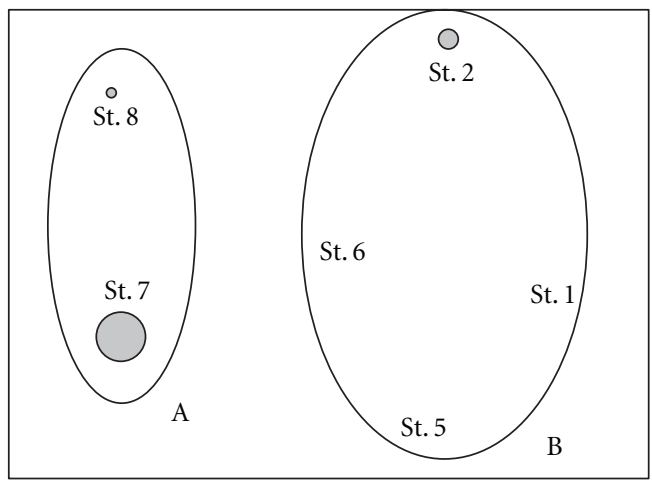

(d)

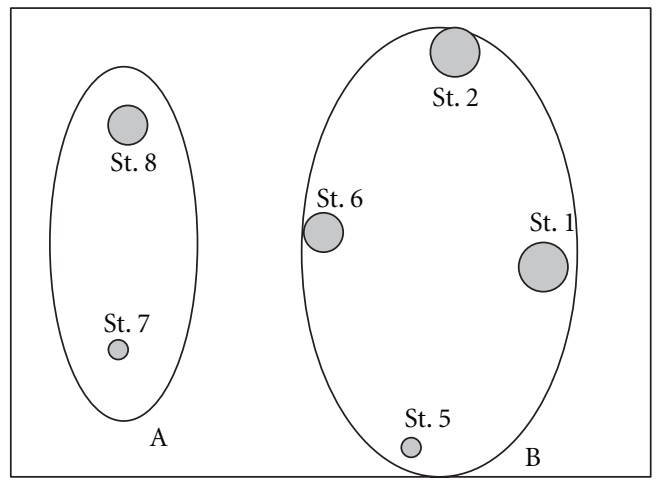

(f)

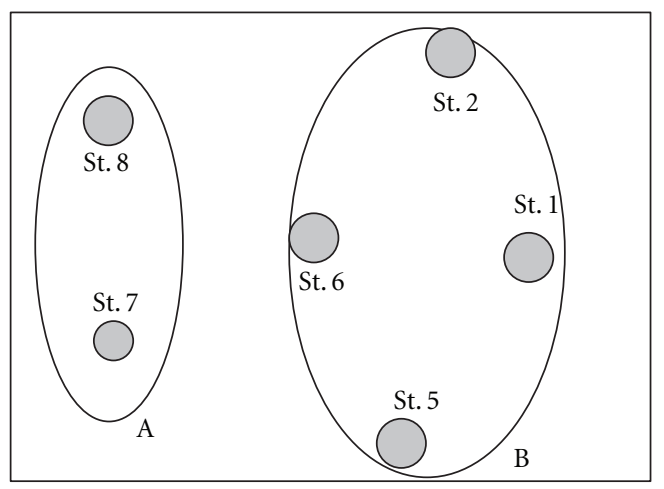

$(\mathrm{g})$

FIGURE 4: Environmental variables superimposed in each localities on frequency nMDS: (a) gravel, (b) coarse sand, (c) fine sand, (d) slimes and clays, (e) organic matter, (f) selection coefficient, and (g) salinity. 
A final comparison with other tectonic estuaries (e.g., San Francisco Bay, USA or the Gulf of Nicoya, Costa Rica) shows that the benthic macrofauna is similar in their specific richness and composition although the differences in latitudinal location. A total of 537 species (taxa) have been cited for San Francisco Bay (USA) [49] and 205 (using a Smith and McIntyre bottom grab) from the Gulf of Nicoya, Costa Rica [19]. On the other hand, if we compare this tropical bay with other estuaries and coastal zones worldwide, we find a wide range in specific richness, but Bahía Málaga is consistently richer than others regions, for example, the coastal lagoon estuary of Jiaozhou Bay, Yellow sea, China, with 322 species [50], Sao Sebastian Channel, Brazil, 392 species [51], coastal zone of Peru, 175 species, [11, 12], coastal zone of Santa Marta, Colombia (232 genera), [45, 46], Gorgona island, Colombia, 200 species [25].

In summary, this research confirms certain hypotheses about the factors that determine the benthic macrofauna abundance and distribution patterns. First, the submerged bottoms of this tectonic estuary are essentially similar in species composition to other types of estuaries of the Tropical eastern Pacific; however, it has a higher number of species as a consequence of the higher number of habitats (substrate heterogeneity), in this way, marine-specific richness and biological diversity are related to a higher variety of habitats. Second, rocky habitats have a higher diversity of benthic fauna than mangrove and mudflat habitats in the same bay, the latter having few species as a consequence of temperature and salinity variations. Besides this condition, the most important factors controlling the macrofauna distribution are variables associated to diversity of habitats and characteristics of the sediments and substrate and not with the estuarine gradients of environmental variables of the water column.

\section{Acknowledgments}

This paper was part of the project Valoración de la biodiversidad marina y costera de Bahía Málaga (Valle del Cauca, Pacífico colombiano): uno de los insumos para respaldar su declaratoria como área protegida (no. 210509-16821), partly funded by the Instituto Colombiano para el Desarrollo de la Ciencia y la Tecnología "Francisco José de Caldas" (Colciencias), the Instituto de Investigaciones Marinas $y$ Costeras "José Benito Vives de Andreis" (Invemar), Universidad del Valle (Univalle) and the Instituto para la Investigación y Preservación del Patrimonio del Valle del Cauca (Inciva). The authors give special thanks to Juan Lazarus, Luz Ángela López de Mesa, Raúl Neira, and Germán Bolívar for the help in the identification of organisms and suggestions for processing the data, Fabian Cortés for help in providing statistical information, as well as, the BIOMÁLAGA team for their support during the samplings. The authors would also like to thank Philip A. Silverstone-Sopkin, Paul Debruyn, and Edgardo Londoño for their corrections of the English version. The authors are grateful for the support of the publication to the Interadministrative Agreement Number 05 of 2011 INVEMAR-MAVDT.

\section{References}

[1] J. W. Day, C. J. Hall, W. M. Kemp, and A. Yañez-Arancibia, Estuarine Ecology, Wiley Interscience Publication, New York, NY, USA, 1989.

[2] B. Kjerve, "Manual for investigation of hydrologic processes in mangrove Ecosystems," UNESCO/UNDP Regional Project: Mangroves of Asia and the Pacific RAS/86/120, 1990.

[3] C. H. Peterson, H. C. Summerson, E. Thomson et al., "Synthesis of linkages between benthic and fish communities as a key to protecting essential fish habitat," Bulletin of Marine Science, vol. 66, no. 3, pp. 759-774, 2000.

[4] M. Bertness, S. Gaines, and M. Hay, Marine Community Ecology, Sinauer Associates Inc, Sunderland, Mass, USA, 2001.

[5] A. Vallega, Fundamentals of integrated coastal management, Kluewer Academic Publishers, Dordrecht, The Netherlands, 1999.

[6] H. Theede, A. Ponat, K. Hiroki, and C. Schlieper, "Studies on the resistance of marine bottom invertebrates to oxygendeficiency and hydrogen sulphide," Marine Biology, vol. 2, no. 4, pp. 325-337, 1969.

[7] F. Carrasco and V. Gallardo, "Abundance and distribution of the macrobenthic infauna of the Gulf of Arauco," Chile. Hydrobiology, vol. 68, no. 6, pp. 825-838, 1983.

[8] J. C. Cantera, Etude structurale des mangroves et des peuplements macrobenthiques littoraux de deux bailes du pacifique colombien (Málaga et Buenaventura) rapport avec les conditions du milieu et les perturbations anthropiques, Ph.D. thesis, A l'Universite d'Aix Marseille II Faculte Sciences de Luminy, Marseille, France, 1991.

[9] D. Maurer, C. Epifanio, H. Dean et al., "Benthic invertebrates of a tropical estuary: gulf of Nicoya, Costa Rica," Journal of Natural History, vol. 18, no. 1, pp. 47-61, 1984.

[10] J. A. Vargas, “The benthic community of an intertidal mud flat in the Gulf of Nicoya, Costa Rica. Description of the community," Revista de Biologia Tropical, vol. 35, no. 2, pp. 299-316, 1987.

[11] J. Tarazona, W. Arntz, E. Canahuire, Z. Ayala, and A. Robles, "Modificaciones producidas durante El Niño en la infauna bentónica de áreas someras del ecosistema peruano," Boletín Instituto del Mar del Perú, pp. 55-63, Volumen Extraordinario, 1985.

[12] W. Arntz, J. Tarazona, V. Gallardo, L. Flórez, and H. Salzwedel, "Benthos communities in oxygen deficient shelf and upper slope areas of the Peruvian and Chilean Pacific coast and changes caused by El Niño," in Modern and Ancient Continental Shelf Anoxia, R. Tyson and T. Pearson, Eds., vol. 58, pp. 154-131, Geological Society Special Publications, 1991.

[13] V. A. Gallardo, "Efectos del fenómeno de El Niño sobre el bentos sublitoral frente a Concepción, Chile," in El Niño y su Impacto en la Fauna Marina, W. Arntz, A. Landa, and J. Tarazona, Eds., pp. 79-85, Instituto del Mar del Perú, 1985.

[14] V. A. Gallardo, R. Roa, F. D. Carrasco, J. I. Cañete, S. EnríquezBriones, and M. Baltazar, "Bathymetric and seasonal patterns in the sublittoral megafauna off central Chile," Journal of the Marine Biological Association of the United Kingdom, vol. 76, no. 2, pp. 311-326, 1996.

[15] S. P. Ferraro and F. A. Cole, "Effects of DDT sedimentcontamination on macrofaunal community structure and composition in San Francisco Bay," Marine Biology, vol. 130, no. 2, pp. 323-334, 1997.

[16] C. Neira, L. A. Levin, and E. D. Grosholz, "Benthic macrofaunal communities of three sites in San Francisco Bay invaded 
by hybrid Spartina, with comparison to uninvaded habitats," Marine Ecology Progress Series, vol. 292, pp. 111-126, 2005.

[17] B. Thompson, "Variation in benthic assemblages in Southern California Coastal," Water Research Project Biennial Report, The Southern California Coastal Water Research Project, Westminster, Calif, USA, 1982.

[18] B. Thompson, H. Peterson, M. Kellogg, and S. Lowe, "Progress report on the benthic pilot study," in Proceedings of the Annual Report: San Francisco Estuary Regional Monitoring Program for Trace Substances, pp. 129-141, San Francisco Estuary Institute, Oakland, Calif, USA, 1996.

[19] D. Maurer and J. A. Vargas, "Benthic studies in the Gulf of Nicoya, Costa Rica," Contribuciones Científicas, vol. 2, pp. 256367, 1985.

[20] J. A. Vargas, "The Gulf of Nicoya Estuary, Costa Rica: past, present, and future cooperative research," Helgoländer Meeresuntersuchungen, vol. 49, no. 1-4, pp. 821-828, 1995.

[21] H. V. Prahl, J. Cantera, and R. Contreras, Manglares y Hombres del Pacífico Colombiano, Folio Ltda, Bogotá, Colombia, 1990.

[22] D. Dexter, "Sandy-beach fauna of the Pacific and Atlantic coasts of Costa Rica and Colombia," Revista de Biología Tropical, vol. 22, no. 1, pp. 51-66, 1974.

[23] J. Cantera, P. Arnaud, and R. Neira, "La macrofauna de playas arenosas en las bahías de Buenaventura y Málaga (Pacífico colombiano): estructura espacial y dinámica temporal," $R e$ vista de Ciencias, vol. 10, pp. 27-48, 1994.

[24] J. R. Cantera, B. A. Thomassin, and P. M. Arnaud, "Faunal zonation and assemblages in the Pacific Colombian mangroves," Hydrobiologia, vol. 413, pp. 17-33, 1999.

[25] F. Cortés, Fauna macro-bentónica asociada a sustratos blandos y su relación con factores medioambientales en el Parque Nacional Natural Gorgona, Pacífico Colombiano, Tesis de Grado, Universidad del Valle, Cali, Colombia, 2001.

[26] C. H. Lucero, J. R. Cantera, and I. C. Romero, "Variability of macrobenthic assemblages under abnormal climatic conditions in a small scale tropical estuary," Estuarine, Coastal and Shelf Science, vol. 68, no. 1-2, pp. 17-26, 2006.

[27] J. Cantera and J. Blanco, "The estuary ecosystem of Buenaventura bay," in Coastal Marine Ecosystems of Latin America, U. Seeliger and B. Kjerve, Eds., vol. 144, pp. 265-280, Ecological Studies, 2001.

[28] O. Solano, F. Cortés, and J. Ruíz-López, "Ambientes y Comunidades de Fondos Blandos," in Gorgona Marina: Contribución al Conocimiento de una Isla Única, L. M. Barrios and M. LópezVictoria, Eds., Serie Publicaciones Especiales. No. 7, pp. 65-77, INVEMAR, Santa Marta, Colombia, 2001.

[29] Invemar, Univalle, and Inciva, "BIOMÁLAGA: valoración de la biodiversidad marina y costera de Bahía Málaga (Valle del Cauca), como uno de los instrumentos necesarios para que sea considerada un área protegida," Cali, Colombia. Informe Científico. Final. INVEMAR- UNIVALLE-INCIVA, 2006.

[30] Cenipacífico, Impacto ecológico en Bahía Málaga a raíz de los desarrollos de la Base Naval del Pacífico y carretera de acceso, Tomo I y II, 1986.

[31] L. Gidhagen, Introducción a la Oeanografía Física y Química, Universidad del Valle, Cali, Colombia, 1982.

[32] WWF and CENIPACIFICO, "Declaratoria de la zona marina y estuarina de Bahía Málaga como área marina protegida," Documento Técnico 056, 2007.

[33] IDEAM, "Condiciones e indicadores ambientales en Colombia," Informe Técnico, vol. 123, pp. 45-46, 2005.

[34] IDEAM, "Condiciones e indicadores ambientales en Colombia," Informe Técnico, vol. 126, pp. 48-49, 2005.
[35] I. Malikov and G. Camacho, "Método de aproximación para determinar cambios entre anuales aplicado a parámetros de temperatura y salinidad del Pacífico colombiano," Boletín Científico del CCCP, vol. 7, pp. 30-41, 1998.

[36] N. Holme and A. McIntyre, Methods for the Study of Marine Benthos, Blackwell Scientific Publications, London, UK, 1st edition, 1971.

[37] J. Gray, A. McIntyre, and J. Stim, "Manual of methods in aquatic environment research. Part 11. Biological assessment of marine pollution with particular reference to benthos," FAO Fisheries Technical Paper No 324, FAO, Roma, Italy, 1992.

[38] J. Ludwig and J. Reynolds, Statistical Ecology. A. Primer on Methods and Computing, John Wiley \& Sons, New York, NY, USA, 1988.

[39] R. M. Warwick and K. R. Clarke, "Relearning the ABC: taxonomic changes and abundance/biomass relationships in disturbed benthic communities," Marine Biology, vol. 118, no. 4, pp. 739-744, 1994.

[40] J. Kruskal and M. Wish, Multidimensional scaling. Quantitative applications in the Social, Sciences Series, Sage Publications, Newbury Park, Calif, USA, 1978.

[41] K. Clarke and R. Warwick, Change in Marine Communities: An Approach to Statistical Analysis and Interpretation, chapter 17, Primer-E. Ltd, Lvybridge, UK, 2nd edition, 2001.

[42] J. Kaandorp, "Rocky substrate communities of the infralittoral fringe of the Boulonnais coast, NW France: a quantitative survey," Marine Biology, vol. 92, pp. 255-265, 1986.

[43] M. Cuartas, J. Ramos, and J. Restrepo, "Variaciones temporales de la fauna macrobentónica intermareal en la playa de la Isla El Choncho (Delta del Río San Juan Pacífico colombiano). Delta del Río San Juan Bahías Málaga y Buenaventura Pacífico Colombiano," Tomo I, pp. 160-171, 1995.

[44] J. Gray, The ecology of marine sediments. An introduction to the structure and function add the shallow sublittoral benthos, Cambridge University Press, Cambridge, UK, 1981.

[45] A. Guzmán-Alvis, O. Solano, M. Córdoba-Tejada, and A. López-Rodríguez, "Comunidad macro-infaunal de fondos blandos someros tropicales (Caribe colombiano)," Boletín de Investigaciones Marinas y Costeras, vol. 30, pp. 39-66, 2001.

[46] A. Guzmán-Alvis, La comunidad macro-zoobentonica de fondos blandos de la plataforma continental del departamento del Magdalena (Caribe colombiano), M.S. thesis, Universidad Nacional de Colombia, Santa Marta, Colombia, 1993.

[47] D. Alongi, "The ecology of tropical soft-bottom benthic: review with emphasis on energetic concepts," Revista de Biología Tropical, vol. 37, no. 1, pp. 85-100, 1990.

[48] M. J. Attrill and S. D. Rundle, "Ecotone or ecocline: ecological boundaries in estuaries," Estuarine, Coastal and Shelf Science, vol. 55, no. 6, pp. 929-936, 2002.

[49] B. Thompson, S. Lowe, and M. Kellogg, "Benthic Pilot Study 1994-1997 Part 1-macrobenthic assemblages of the San Francisco Bay-Delta and their responses to abiotic factors San Francisco estuary regional monitoring program for trace substances," Tech. Rep., 2000.

[50] H. Yu, X. Li, B. Li, J. Wang, and H. Wang, "The biodiversity of macrobenthos from Jiaozhou Bay," Acta Ecológica Sinica, vol. 26, pp. 416-422, 2006.

[51] E. Arasaki, P. Muniz, and A. Pires-Vanin, "A Functional analysis of the benthic macrofauna of the São Sebastião Channel," Marine Ecology, vol. 25, no. 4, pp. 249-263, 2004. 

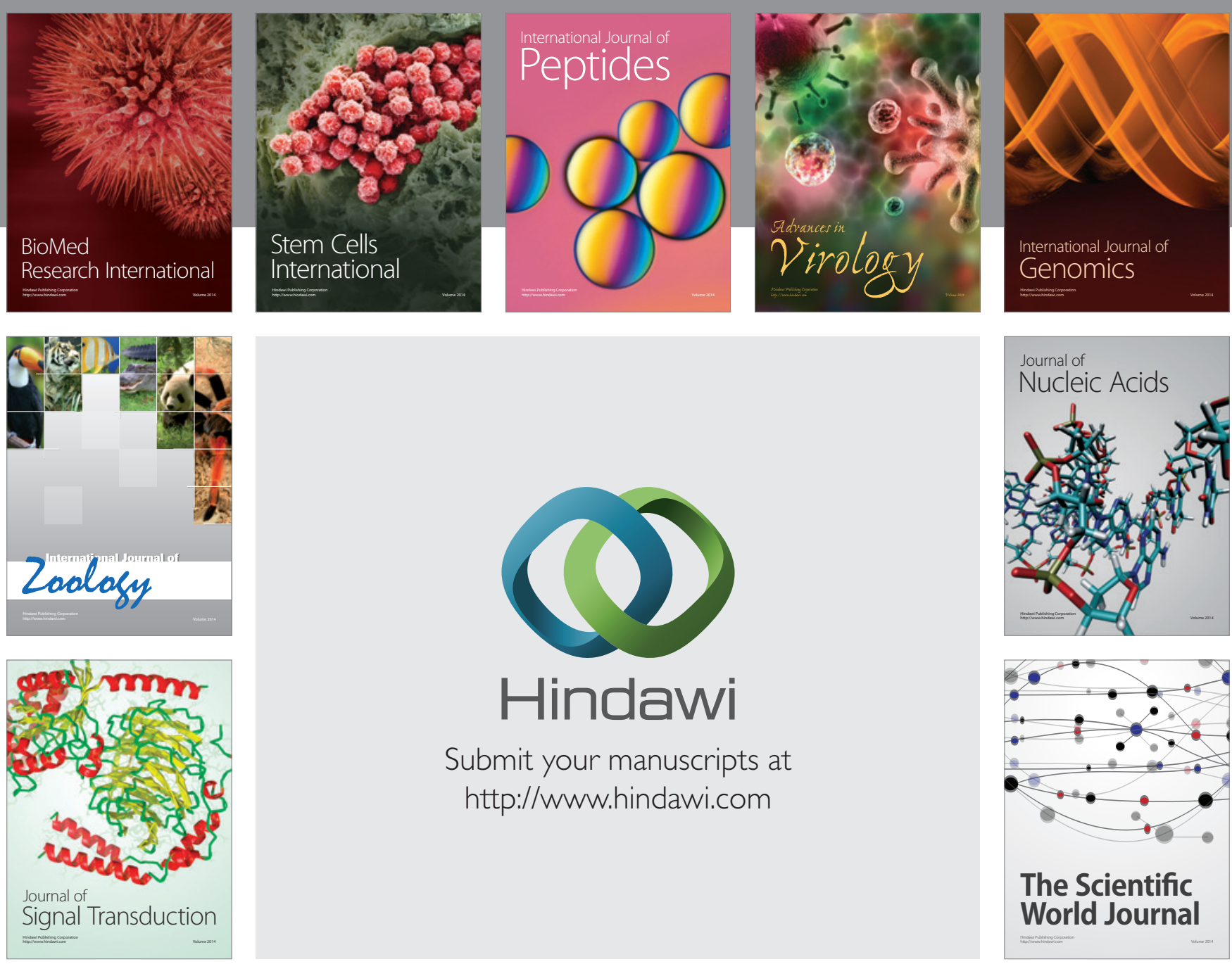

Submit your manuscripts at

http://www.hindawi.com
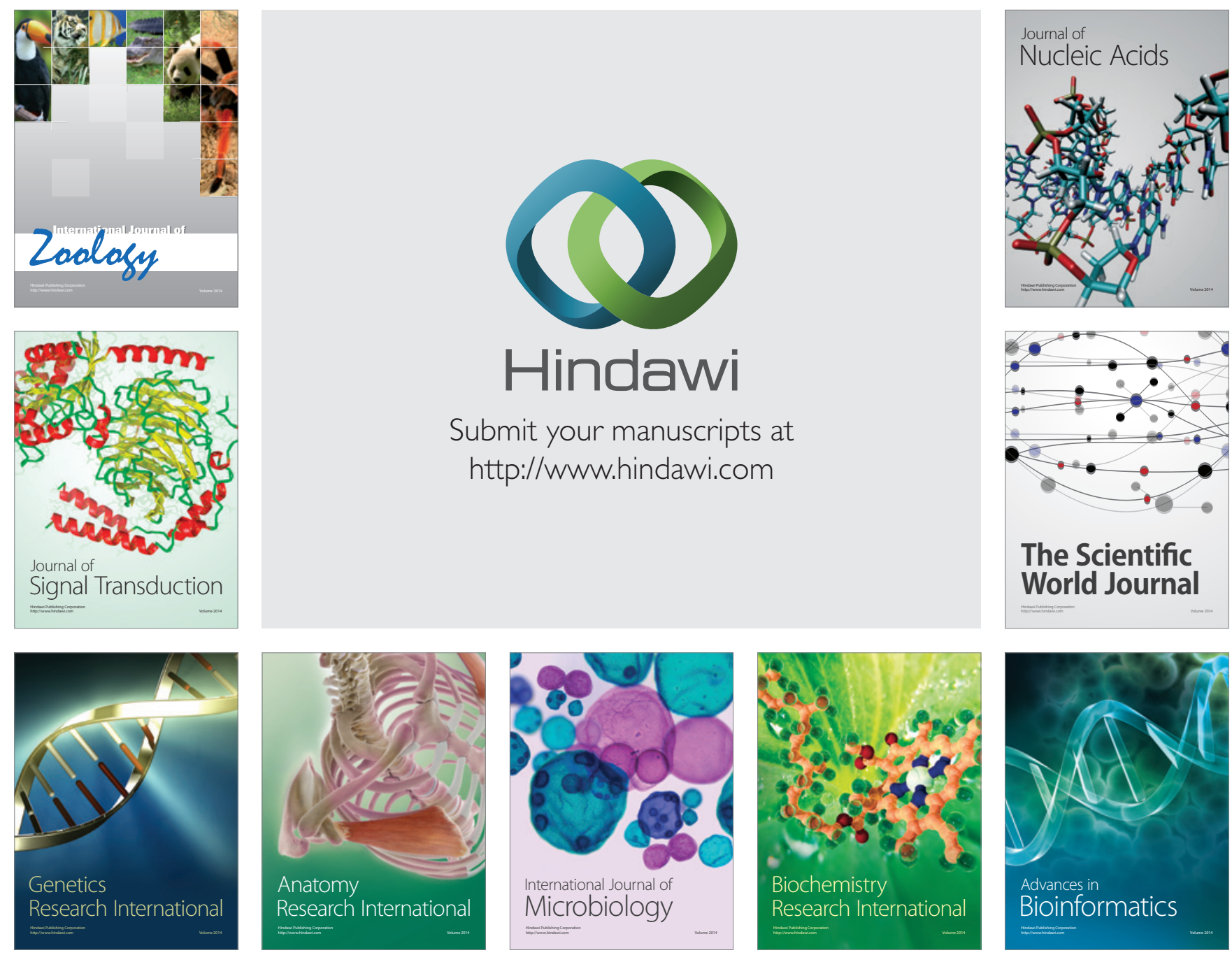

The Scientific World Journal
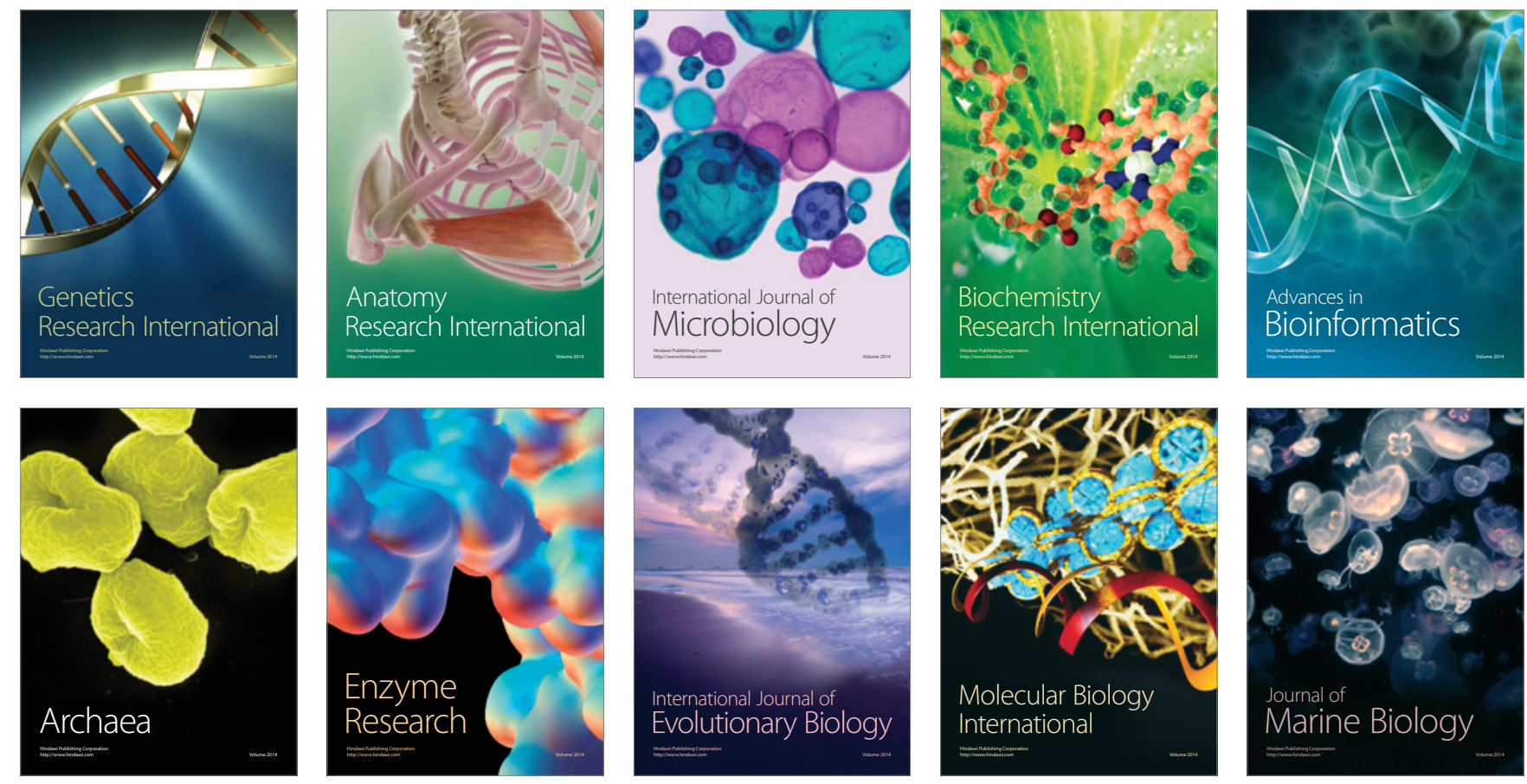